\title{
Environmental Management Systems in Euganean Hills Regional Park
}

\author{
A. Scipioni, A. Mazzi, F. Zuliani, A. Morelli \& M. Mason \\ University of Padua, Department of Chemical Engineering Processes, \\ Quality and Environmental Studies Centre, Padua, Italy
}

\begin{abstract}
The project started in January 2003 as an initiative of the Euganean Hills Regional Park in collaboration with Padua University and territorial Authorities, and involves five municipalities of the Euganean Thermal Area.

The target is to implement five Environmental Management Systems (EMS), one for each municipality concerned, which want to adopt an observing legal prescriptions' Environmental Policy, and commit themselves to introduce measures for an effective and continuous improvement of the environmental performance and to put transparent communication with stakeholders into effect.

The programme, proposed to the European Community jointly with other projects of different European partners and co-financed by the European Commission (ERDF Funding), is a pilot scheme set in an IPAM-Toolbox (Integrative Protective Area Management), in order to promote the sustainable management of protected areas, and the exchange of good practices.

This project is now in its last stage. Its implementation allowed the municipalities involved to provide for the Initial Environmental Analysis study, identify direct and indirect environmental aspects and impacts, check environmental legislative conformity, define an Environmental Policy, implement five EMS, improve stakeholders' environmental awareness through the circulation of the "Environmental Statement" and the meetings organization. Two municipalities became registered EMAS between 2005 and 2006.

Keywords: Environmental Management Systems, sustainable management in protected areas, environmental aspects and impacts.
\end{abstract}

\section{Introduction}

The project proposed in this paper has involved since 2003 The Euganean Hills Regional Park with the main aim to achieve the EMAS registration for the five 
Municipalities of the Thermal Euganean District, as an acknowledgement of their excellence in the management of the environmental issues of the area.

The project put himself in a wider context, the IPAM project (Integrative Protected Area Management), realized at a Community level in cooperation with other European partners, representative of various public bodies from different European countries, with the common purpose of developing and transferring good practices for the environmental management of the protected area [1].

In particular, referred to the Euganean Hills Regional Park, the municipalities involved in the programme are: Abano Terme, Battaglia Terme, Galzignano Terme, Montegrotto Terme e Teolo. They all lies in the Thermal Euganean District, in the Venetian Region, in the north-east of Italy, which is a valuable area for tourism, thanks to the thermal bath and the naturalistic potential of its territory [2].

The project arose from the need, of the Euganean Hills Regional Park, to promote environmental safeguard activities and to stimulate local administrations of the Park region to adopt a shared environmental policy. The project of the EMAS Registration of the Thermal Euganean district wants to provide the Administrations with an acknowledged environmental tool that helps them defining environmental targets and strategies.

The achieving of EMAS registration for each municipal Administration involved means a great goal. Nevertheless, the whole process that drove these localities in the definition of an environmental policy and of an environmental management system, assumes a big relevance as it proves how, in a strategic long term perspective, the Thermal District gains a continuous improvement of its environmental performances toward local sustainable development.

The main objects of the project are to allow the bodies that manage the Thermal Euganean District and the economical activities within its territory to [3]:

- plan, act and manage territorial problems in a coordinated and integrated manner;

- monitor and improve the performances of the subjects that acts on the territory;

- awake stakeholders on environmental improvement;

- promote the area and its activities both nationally and internationally, giving evidences of how the territory put into practice actions of environmental protection and how the area meets the tourists and the visitors expectations;

- answer specific economical needs like the promotion of economical activities relevant to the thermal sector and the safeguard of the natural landscape.

\section{Methodology}

EMAS (Eco Management and Audit Scheme) is the Community system for the eco-management and audit set by the Regulation (CE) n. 761/2001, with the aim 
to promote continuous environmental improvement, trough the adoption and the implementation of a management system in the public and private bodies and organizations [4].

Organizations that join EMAS must draw up an environmental policy directed to assure the respect of limits and binding forces imposed by the regulation, and must undertake to realize actions of concrete and continuous improvement of their environmental performances $[4,5]$. To hit specific environmental targets, organizations must adopt an environmental management system, promote an active involvement of their employees and set a clear and active communication with public, through the publication of a document called "Environmental Statement" [4, 5].

The EMAS Registration project for the Thermal Euganean District, formerly started on the 10th of Gennuary 2003 with the subscription of a Programme Agreement between the Euganean Hills Regional Park, as coordinator and promoter of the activities, five Municipalities of the Thermal Euganean District (Abano Terme, Battaglia Terme, Galzignano Terme, Montegrotto Terme e Teolo), Province of Padova, Regional Agency for Environmental Prevention and Protection of Venetian Region (ARPAV) and Regional Agency for Agricultural, Forestal and Agri-food sectors (Veneto Agricoltura) [6].

The Agreement formalizes the commitment of every single body in reaching the common target of an integrated territorial management, defining roles, responsibilities and resources.

The EMAS Registration project for the Thermal Euganean District, promoted by the Euganean Hills Regional Park also at a European level, was included as a Regional Pilot Action within a project called Interreg III B CADSES IPAM Toolbox, co-financed by the European community and by the Italian Ministry of Infrastructures and Transports [1].

The partners of IPAM project in Europe are: PRCE (Euganean Hills Regional Park), Federal State Government of Carinthia (Lead Partner), Federal State Government of Styria, Regional Directorate of Parks of Autonomous Region of Friuli, Academy of Sciences of Czech Department for Spatial Planning in Medimurje County of Croazia, Ministry of Environment, Spatial Planning and Energy of Republic of Slovenia [1].

The project IPAM - Toolbox is focused on the evaluation, harmonisation and development of methods, instruments and infrastructures for planning and managing protected areas. The individual tools encompassed are linked by specific interfaces to a systemic "Toolbox": e.g. managing plans, monitoring systems, visitor management, and conservation by contracts. A broad theoretical and transnational approach was completed by regional pilot actions which were implemented in target-regions in Austria, Italy, Croatia and the Czech Republic. All partners - including Slovenia - contributed with their know-how to the discussion process.

Based on a transnational database, a C.A.S. - Computer Aided System was developed. This helps in the identification of problems, proposed instruments and tools and provides examples of Best Practice. An extensive transnational 
transfer of know-how and experiences is intended by means of workshops, conferences, excursions and the establishment of virtual teams via the homepage of the project.

The regional pilot actions were focused on the generation of "visible results" for the solution of concrete problems. They involved regional initiatives and administrative bodies, supported local implementation and placed emphasis on communication with regional stakeholders.

This "bottom-up"- approach ensures that the broad spectrum of "practical" aspects is included in the project's general results on a transnational level.

\section{Carrying out of the project and results achieved}

Generally, a project of EMAS Registration, develops through a route defined by the Regulation 761/2001, that starts with the drafting of the Initial Environmental Review, and then continues with the following steps: the definition of an Environmental Policy, the implementation of an Environmental Management System, the identification and implementation of proper formation and sensibilization activities, the designing of environmental performance indicators, the auditing of the implemented system and of its effectiveness through internal environmental audit, the drafting of an Environmental Statement, the environmental auditing by an accredited verifier, the technical audit (in Italy, by APAT, the Environmental and Territorial Agency) and the EMAS Registration from the national Competent Body (in Italy, the ECOLABEL and ECOAUDIT committee, EMAS section) [4 - art. 3].

In particular, in the case of the project for the Thermal Euganean District, to better understand the environmental state of the involved Municipalities, an Initial Environmental Review of the whole area was carried out. Through this document it was possible to identify and report the critical environmental aspects of the region; starting from the criticality identified, the Municipalities involved, were able to assign them different level of significance and than set intervention priorities in the definition of the environmental policy and the Environmental Management System.

Coherently with EMAS Regulation CE 761/2001, the Environmental Review must consider "all environmental aspects of the organisation as a basis for establishing the environmental management system" [7].

In this first stage, all the activities performed by the Municipal Administrations were analyzed in order to consider all the environmental aspects, direct and indirect, and to judge their environmental impact. Also the Environmental Law, applicable to the municipal reality, was examined in order to verify its correct application, stressing the responsibilities and the methods used, in comparison to the bodies' organizational structure.

Six different documents were drawn up and divided in:

- one Initial Environmental Review of the Thermal Euganean District, in which are collected all the data and information relevant to the entire region [8]; 
- five Initial Environmental Review, one for every single Municipality, in which were included all the data and information relevant to the specific environmental situation of every municipality $[9,10,11,12,13]$.

Once the actual situation of the territory was determined, the subjects participating in the project were able to set principles on which base the environmental polices and on which define specific improvement targets of medium-long term. The Environmental polices elaborated and adopted by the Municipalities of the Thermal District, as proposed by the Euganean Hills Regional Park, report the general commitments that move towards the environmental improvement [14, 15].

The Environmental Policy was then published and divulgated through publications and billpostings to the stakeholders inside and outside the Municipality: the municipal employees, residents, tourists, economical activities and their associations.

Basing on the results achieved within the Initial Environmental Review and the strategic contents of the Environmental policy adopted by every single Municipality, the Environmental Management System of the five Municipalities involved were structured, defining methods and responsibilities of the activities management relevant to the prominent environmental aspects and their impacts and for the implementation of structural processes provided with the Environmental Management System itself, according to the EMAS Regulation requirements.

Coherently with what is provided with the EMAS Regulation, Organisations participating in the eco-management and audit scheme (EMAS) shall implement the requirements of EN ISO 14001:2004" [16, 17, 18].

So, every single Municipality developed its own Environmental Management System [19]:

- defining the methods to implement the Environmental Policy and the environmental programs for the improvement to reach the environmental targets and goals;

- $\quad$ identifying the organizational structure and the subjects involved in the implementation of the Environmental Management System;

- identifying practices, procedures, internal regulations, processes, resources and responsibilities to carry out the Environmental Management System;

- defining the education level of the staff and the methodology to spread and divulge all the information relevant to the environmental improvement;

- $\quad$ put into action an operative control of the activities and services which have critical impacts on environment;

- determining corrective actions in order to adapt the system to new external realities, like new requisites of the applicable regulations, new environmental priorities, environmental emergencies, etc.; 
- developing control methods of the Environmental Management System with the aim to assure continuous environmental improvement of the area;

- drawing the documentations of the system and providing to its divulgation.

The introduction of an Environmental Management System in the realities of Municipal Administration must be supported by staff education and sensitizations initiatives.

That is why educational activities were planned not only for the ones responsible of the Management System but for all the staff of the Municipality. These educational meetings were carried out in order to divulge the fundamental principles of the environmental management and then show the main characteristics and the operational methods provided for the Environmental Management system during its implementation.

Basing on the data collected during the implementation of the Initial Environmental Review and the Environmental Management System, and following the guidelines provided by ISO 14031 [20], proper indicators were chosen to assure the monitoring and measurement of the environmental performances of the Municipalities involved and the activities within the area.

Every single Municipality, therefore, worked out an appropriate database and built indicators, to allow the retrieving of reliable information relevant to local environmental performances of every single environmental direct and indirect aspect analyzed and found in the municipal territory.

For example, chosen indicators allowed to assess all of the energy, potable water and natural gas consumption relevant to all the Municipal buildings and to the whole area.

The analysis of the values assumed by the indicators, let the identification of possible area for the environmental improvement on which administration should set environmental programs defining concrete targets and goals.

Such indicators, intentionally designed to allow an easy reading and immediate comprehension, were than used by the municipal administration also to communicate the citizens, the tourist and the economical operators on the actions started towards environmental improvement and environmental quality of the locality itself.

Once this stage ended, an internal auditing cycle was planned with the aim to monitor the effectiveness of the Environmental Management System [21].

All the steps of the internal environmental auditing program were coordinated and checked by Euganean Hills, while qualified experts managed the audits.

The objects of the audits were to monitor and verify:

- conformity to the actions provided for the Environmental Management System and the environmental improvement program required by EMAS regulation 761/2001;

- effectiveness of the undertaken actions toward the improvement of the environmental performances and toward the implementation of the environmental policies defined. 
Once the audits were concluded, corrective and preventive actions were defined in order to answer the non-conformity identified.

Therefore, an Environmental Statement, in conformity with the requirements of the Regulation 761/2001- Annex III, applicable to the Municipalities of the Euganean Thermal District, was drawn up. Then, the definitive revisions of the Environmental Statements were edited.

As provided by EMAS regulation "The aim of the environmental statement is to provide environmental information to the public and other interested parties regarding the environmental impact and performance and the continual improvement of environmental performance of the organisation. It is also a vehicle to address the concerns of interested parties identified [...]. Environmental information shall be presented in a clear and coherent manner in printed form for those who have no other means of obtaining this information" [22].

These documents are the main communication and promotion devices of all the project till know described, as they conciliate the objective formalization needs of the performances of the environmental improvement and the needs of divulgation, easy reading and effectiveness promotion of the area itself.

In the Environmental Statement of the Euganean Thermal District [23, 24] was included information such:

- a synthesis of the main activities and services that are placed in the territory and the description of the critical environmental aspects and impacts;

- the environmental policy, the environmenatl targets and goals defined and the environmental program put into action in order to hit the evironmental targets and goals;

- a brief description of the Environmental Management System implemented, and the indication of the main responsabilities on the environmental matters;

- a series of quantitative data that clearly and completely demonstrate the environmental performances of the area, nevertheless the effectiveness of the Environmental Management System implemented to manage all the significative environmental aspects and to hit the targets and goals defined.

The route set with the project for every single municipality should have ended with the environmental audit by an Accredited Environmental Verifier.

On July 2005 the Municipalities of Abano Terme and Galzignano Terme positively passed the audit conducted by an Accredited Environmental Verifier, who validated the Environmental statement.

Between December 2005 and Gennuary 2006 the Italian Emas section of the Ecolabel and Ecoaudit Committee decided the registration of both the municipalities, assigning the numbers I-000420 to Abano Terme and I-00404 to Galzignano Terme. The two Municipalities are issued to the European Register of the registered organizations in conformity with the requirements of the Regulation CE 761/2001 - EMAS. 
In the other municipalities, Battaglia Terme, Montegrotto Terme and Teolo, the project is still in progress and will end in different times and with different modalities.

\section{Conclusions}

Nowdays the project is not yet ended, a new Programme Agreement were subscribed to prolong the time of the project to the end of June 2006. The new Programme Agreement assures the support to the Municipalities which got registered and the ones who want to get the registration [25].

To remark the results of the project it's important to underline some aspects.

For first, the realization of a project that involved different localities allowed the creation of a workgroup with different but complimentary competences in order to coherently face the analysis and management of the environmental matters.

This permitted to:

- make a fast and slender data and informations retrieval;

- share experiences in the environmental management matter and solve the environmental problematics during the Initial Environmental Review, in a common way;

- $\quad$ invest in the specific education of the municipal technicals and the development of a motivated and sensitized team of municipal technicals;

Moreover, it's important to underline how the development of such a common project, between the different local realities, let the offices and the administrations to get closer, thanks to the steps provided by EMAS, helped the growth of the dialogue between parts, sensitizing and involving the municipal staff, the citizens and the stakeholders.

The implementation of the project in every single Municipality involved and in the Euganean Regional Park, allowed the reaching of other positive results:

- the involvement of category associations of the economical activities of the territory, like hotel associations or syndicates, with which the Protocol Agreement, that formalized the common intents for the environmental protection, was subscribed;

- the spread of knowledge, also through audit in sites, of the main criticality of the territory, like depurators and industrial activities which have impacts on the environment;

- $\quad$ the definitions of targets and concrete and effective environmental improvement programs, able to improve the local environmental performances.

Finally, one of the element that makes this project innovative, is the realization of a territorial data base and the creation of environmental performances indicators, able to give a tool for monitoring the condition of the environment and the effectiveness of the undertaken actions, both from a pressure and answer perspective, in consideration of the data and information collected relevant to the whole area. 
The subjects involved are the bodies responsible of the data retrieval. These are: institutional bodies for the environmental control (eg. ARPAV) industrial organizations, category organizations, as subjects responsible of the management of the territory.

Indicators represent the main input on which define policies and actions of the development and the safeguard of the territory: on the basis of this information, many different considerations may be structured every time the Administration will have to define new actions and projects.

\section{References}

[1] INTERREG III B CADSES IPAM, IPAM Toolbox: Integrated Protected Area Management, 2003, http://www.eurositenature.org/IMG/pdf/015_ipam_toolbox.pdf.

[2] Bartolomei S., Scipioni A., Morelli A., Zuliani F., Il Progetto di Registrazione EMAS dei Comuni appartenenti al Bacino Termale del Parco Regionale dei Colli Euganei, Final Report INTERREG III B CADSES IPAM Toolbox.

[3] Bartolomei S., Scipioni A., Morelli A., Zuliani F., EMAS application in the Euganean Thermal Basin. Proc. of the $3^{\text {rd }}$ Symposium of the Hohe Tauern National Park for Research in Protected Areas, Castle of Kaprun, p. 19, 2005.

[4] European Parliament and the Council, Regulation (EC) $n^{\circ} 761 / 2001$ of the European Parliament and of the Council of 19 March 2001 allowing voluntary participation by organisations in a Community ecomanagement and audit scheme (EMAS), European Parliament and the Council, 2001.

[5] European Commission, Commission Recommendation of 7 September 2001 on guidance for the implementation of Regulation (EC) $n^{\circ} 761 / 2001$ of the European Parliament and of the Council allowing voluntary participation by organisations in a Community eco-management and audit scheme (EMAS), European Commission, 2001.

[6] Euganean Hills Regional Park, Province of Padova, Municipalities of Thermal Euganean District (Abano Terme, Battaglia Terme, Galzignano Terme, Montegrotto Terme e Teolo), Regional Agency for Environmental Prevention and Protection of the Venetian Region (ARPAV), Regional Agency for Agricultural, Forestal and Agri-food sectors (Veneto Agricoltura), Accordo di Programma per la realizzazione nel Bacino Termale Euganeo di un Sistema di Gestione Ambientale Territoriale conforme al Regolamento $n^{\circ} 761 / 2001 C E$ ed il conseguimento della Registrazione EMAS, 10 January 2003.

[7] European Parliament and the Council, Regulation (EC) $n^{\circ} 761 / 2001$, Annex VII "Environmental review", European Parliament and the Council, 2001. 
[8] AA.VV., Rapporto di Analisi Ambientale Iniziale del Bacino Termale Euganeo, Territorio dei Comuni di: Abano Terme, Battaglia Terme, Galzignano Terme, Montegrotto Terme e Teolo, Euganean Hills Regional Park, June 2004.

[9] AA. VV., Rapporto di Analisi Ambientale Iniziale del Comune di Abano Terme, Abano Terme Municipality, April 2004.

[10] AA. VV., Rapporto di Analisi Ambientale Iniziale del Comune di Battaglia Terme, Battaglia Terme Municipality, April 2004.

[11] AA. VV., Rapporto di Analisi Ambientale Iniziale del Comune di Montegrotto Terme, Montegrotto Terme Municipality, April 2004.

[12] AA. VV., Rapporto di Analisi Ambientale Iniziale del Comune di Galzignano Terme, Galzignano Terme Municipality, April 2004.

[13] AA. VV., Rapporto di Analisi Ambientale Iniziale del Comune di Teolo, Teolo Municipality, April 2004.

[14] AA. VV., Politica Ambientale del Comune di Abano Terme, Abano Terme Municipality, December 2005.

[15] AA. VV., Politica Ambientale del Comune di Galzignano Terme, Galzignano Terme Municipality, January 2006.

[16] European Commission, Commission Regulation (EC) $N^{\circ} 196 / 2006$ of 3 February 2006 amending Annex I to Regulation (EC) $n^{\circ} 761 / 2001$ of the European Parliament and of the Council to take account of the European Standard EN ISO 14001: 2004, and repealing Decision 97/265/EC, European Commission, 2006.

[17] ISO, ISO 14001:2004 Environmental management systems Requirements with guidance for use, International Standard Organization (ISO), 2004.

[18] ISO, ISO 14004:2005 Environmental management systems - General guideline on principles, systems and support technique, International Standard Organization (ISO), 2005.

[19] Certiquality, Guidelines to adopt the Environmental Management System by the Public Administration (Linea guida per l'attuazione del Sistema di Gestione Ambientale presso gli enti della Pubblica Amministrazione), Certiquality, 2003.

[20] ISO, ISO 14031:2000 Environmental management - Environmental performance evaluation - Guidelines, International Standard Organization (ISO), 2000.

[21] European Parliament and the Council, Regulation (EC) $n^{\circ} 761 / 2001$, Annex II "Requirements concerning internal environmental auditing", European Parliament and the Council, 2001.

[22] European Parliament and the Council, Regulation (EC) $n^{\circ} 761 / 2001$, Annex III "Environmental statement", European Parliament and the Council, 2001.

[23] AA. VV., Dichiarazione Ambientale convalidata del Comune di Abano Terme, Abano Terme Municipality, December 2005 - Registration $n^{\circ} 420$. 
[24] AA. VV., Dichiarazione Ambientale convalidata del Comune di Galzignano Terme, Galzignano Terme Municipality, January 2006Registration $n^{\circ} 404$.

[25] Euganean Hills Regional Park, Province of Padova, Municipalities of Thermal Euganean District (Abano Terme, Battaglia Terme, Galzignano Terme, Montegrotto Terme e Teolo), Regional Agency for Environmental Prevention and Protection of Venetian Region (ARPAV), Regional Agency for Agricultural, Forestal and Agri-food sectors (Veneto Agricoltura), Thermal Hotels Association (Associazione Albergatori Termali), Accordo di Programma per la realizzazione nel Bacino Termale Euganeo di un Sistema di Gestione Ambientale Territoriale conforme al Regolamento $n^{\circ} 761 / 2001$ CE ed il successivo mantenimento della Registrazione EMAS, 26 January 2006. 